\title{
A modified protocol yields high-quality RNA from highly mucilaginous Dioscorea tubers
}

\author{
Paramananda Barman $^{1} \cdot$ Ashish Kumar Choudhary ${ }^{1}$ R. Geeta ${ }^{1}$
}

Received: 29 November 2015/Accepted: 1 March 2017/Published online: 8 June 2017

(C) Springer-Verlag Berlin Heidelberg 2017

\begin{abstract}
Extraction of RNA from Dioscorea is difficult because of rich mucilage and secondary metabolite content. High-quality RNA is required for RT-PCR and transcriptome analysis. Different protocols and common extraction kits were used for RNA extraction in Dioscorea, but the results were not satisfactory. A CTAB based protocol with lithium chloride precipitation yielded good quality RNA. The RNA isolated using this protocol was successfully used for RT-PCR and transcriptome sequencing experiments. Mucilage content varies at different developmental stages of Dioscorea and the present protocol was effective in isolating RNA from such samples. Although the protocol was originally modified for tuber tissues, it can be used also for extraction of RNA from rhizome, root, shoot and leaf.
\end{abstract}

Keywords RNA extraction - Dioscorea - CTAB - RIN · RT-PCR

\section{Introduction}

The monocot genus Dioscorea contains important tuber crops and species with different medicinal properties. Most species belonging to this genus are tuberous, but a few representatives form rhizomes instead of tubers. Dioscorea has been proposed as an emerging model organism based on its position as an important biological link between the eudicots and grasses, which contain all the model flowering

Paramananda Barman

param.barman@gmail.com

1 Department of Botany, University of Delhi, Delhi 110007, India plant species (Mignouna et al. 2009). Although a few standardized protocols have been reported for isolation of DNA, a standard protocol for extraction of RNA has not been described.

Isolation of good-quality RNA is an essential starting point of molecular biology experiments like RT-PCR and transcriptome sequencing. Extraction of RNA from Dioscorea tubers is problematic due to high mucilage content and presence of secondary metabolites. Our attempt to extract RNA using common protocols using compounds such as TRIzol and guanidinium thiocyanate failed. Due to high mucilage content in the samples, there was clogging of the columns when we attempted RNA extraction using extraction kits. The cetyl trimethyl ammonium bromide (CTAB) protocol for RNA extraction is known to be effective for problematic samples (Chang et al. 1993; Ghangal et al. 2009). Here we present a modified CTAB method for RNA isolation that was successfully used in Dioscorea.

\section{Materials and methods}

\section{Plant material}

Different species and cultivars of Dioscorea were used for RNA extraction. Tubers of Dioscorea alata standard cultivars Sree Keerthi, Sree Karthika, and Sree Roopa were obtained from CTCRI, Thiruvananthapuram, India; D. alata CV 'Far' was collected from Darbhanga, Bihar, India, and the rhizomatous species $D$. deltoidea was collected from Himachal Pradesh, India. All species were grown in the growth facilities of Department of Botany, University of Delhi, Delhi and RNA extraction was attempted with samples collected at different developmental stages. 


\section{Extraction protocol}

Samples for RNA extraction were collected in liquid nitrogen and stored in a $-80{ }^{\circ} \mathrm{C}$ freezer. A clean RNasefree environment is necessary for good-quality RNA extraction; mortars and pestles used for grinding the tissues were treated with $0.1 \%(\mathrm{v} / \mathrm{v})$ diethyl pyrocarbonate (DEPC) overnight, followed by autoclaving to inactivate RNases. All plasticwares were autoclaved before use.

We used CTAB buffer [2\% w/v CTAB reagent, $100 \mathrm{mM}$ Tris-Cl buffer (pH 8.0), $2 \mathrm{M} \mathrm{NaCl}, 25$ mM EDTA (pH 8.0)] containing $2 \% \mathrm{w} / \mathrm{v}$ PVPP and $2 \% \mathrm{v} / \mathrm{v}$ beta-mercaptoethanol (added just before use), following Chang et al. (1993). For extraction, $1 \mathrm{ml}$ of this modified CTAB buffer was added to $100 \mathrm{mg}$ of sample ground in liquid nitrogen and incubated in a water bath at $65{ }^{\circ} \mathrm{C}$ for $20 \mathrm{~min}$, mixing was done at $5 \mathrm{~min}$ intervals by inverting the tubes. After incubation, an equal volume of chloroform-isoamyl alcohol (24:1) was added to the reaction mixture, mixed gently and centrifuged at $15,000 \mathrm{~g}$ for $15 \mathrm{~min}$. The supernatant was collected and an equal volume of phenol-chloroform-isoamyl alcohol (25:24:1; saturated phenol of $\mathrm{pH} 5$ ) was added and mixed gently followed by centrifugation at $4{ }^{\circ} \mathrm{C}$ at a speed of $15,000 \mathrm{~g}$ for $15 \mathrm{~min}$. After centrifugation, an equal volume of chloroform-isoamyl alcohol (24:1) was added to the supernatant and the mixture was centrifuged at $12,000 \mathrm{~g}$ for $10 \mathrm{~min}$. If the supernatant was not clear, then this step (chloroformisoamyl alcohol) was repeated. The clear supernatant of the last chloroform-isoamyl alcohol (24:1) step was transferred to $1.5 \mathrm{ml}$ microcentrifuge tubes, to each of which was added 0.25 volume of $10 \mathrm{M}$ lithium chloride. The tubes were gently inverted a few times and stored at $4{ }^{\circ} \mathrm{C}$ overnight after which they were centrifuged at $15,000 \mathrm{~g}$ for $15 \mathrm{~min}$. The pellet obtained was washed with $4 \mathrm{M} \mathrm{NaCl}$ first and then with $75 \%$ ethanol $(12,000 \mathrm{~g}$ for $15 \mathrm{~min})$. Finally, the air-dried pellet was dissolved in DEPC water and stored at $-20{ }^{\circ} \mathrm{C}$ until use.

\section{DNase treatment (optional)}

DNase treatment was done to remove DNA contamination in the RNA sample. DNase I from NEB (Catalog no M 0303S) was used and the manufacturer's protocol was followed: 2 units enzyme $/ 10 \mu \mathrm{g}$ RNA, incubation at $37{ }^{\circ} \mathrm{C}$ for $10 \mathrm{~min}$ followed by addition of $5 \mathrm{mMEDTA}$ and heat inactivation at $75^{\circ} \mathrm{C}$ for $10 \mathrm{~min}$. However, we found that DNase treatment was generally not necessary when extraction is done using this protocol, so this is an optional step.

\section{RNA quality check}

RNA was resolved and visualized in agarose gel. Agarose gel $(1.5 \%)$ was prepared in $1 \times$ TBE buffer [from a stock $5 \times$ TBE, $54 \mathrm{~g}$ Tris base, $27.5 \mathrm{~g}$ boric acid, and $20 \mathrm{ml}$
0.5 M EDTA (pH 8.0) per liter] with appropriate amount of ethidium bromide. A buffer of $1 \times$ TBE was used for running the gel. RNA quality and quantity were estimated by the spectrophotometric method (Biospectrophotometer instrument, Eppendorf Ltd.; tray cell, Hellma Analytics). Absorbance at 260 and $280 \mathrm{~nm}$ was recorded for all samples.

\section{RNA integrity (RIN) determination}

RNA integrity number (RIN) is an indicator of RNA integrity and is measured in a scale of 1-10 (increasing order of quality). RIN is the scale used for quality control of RNA for next-generation sequencing (NGS) procedures. RNA samples with RIN values in the range of $8-10$ are considered to be of high quality and can be used for transcriptome sequencing (Schroeder et al. 2006). RIN values for our RNA samples were determined using Agilent 2100 bioanalyzer at University of Delhi, South Campus, Delhi and Centre for Cellular and Molecular Platforms (CCAMP), Bangalore.

\section{cDNA synthesis and amplification of genes from the extracted RNA}

Synthesis of cDNA was done using Thermo scientific RevertAid H minus first strand cDNA synthesis kit (Cata$\log$ no \# K1631). The reaction mixture contains template RNA $(1 \mu \mathrm{g})$, oligo $(\mathrm{dT})_{18}$ primer $(1 \mu \mathrm{l}), 5 \times$ reaction buffer $(4 \mu \mathrm{l})$, RiboLock RNase inhibitor, $20 \mathrm{U} / \mu \mathrm{l}(1 \mu \mathrm{l}), 10 \mathrm{mM}$ dNTP Mix $(2 \mu \mathrm{l}), \mathrm{M}-\mathrm{MuLV}$ reverse transcriptase, $200 \mathrm{U} / \mu \mathrm{l}$ $(1 \mu \mathrm{l})$; the final volume of $20 \mu \mathrm{l}$ was made up with DEPC water. The mixture was centrifuged gently and incubated for $60 \mathrm{~min}$ at $42{ }^{\circ} \mathrm{C}$. The reaction was terminated by heating at $70{ }^{\circ} \mathrm{C}$ for $5 \mathrm{~min}$.

The dioscorin (storage protein) gene (partial) was amplified using primers CA 5.1F (GAGGATGAGTTTAG CTACATT) and CA 3.1R (TAAGCATCACCATATT ACACT) designed employing NCBI primer BLAST tool and the software Primer 3 and synthesized at Eurofins Genomics, Bangalore, India. Full-length coding sequence of the dioscorin gene was amplified using the forward primer CA A1F (ATAAATCAAAGAGCCCTCAA) and oligo $(\mathrm{dT})_{18}$ as reverse primer.

PCR components and conditions were as follows. The PCR components used were dNTPs (NEB, Catalog No N0446S), primers, Phusion High-Fidelity DNA polymerase (Cat no M0530S), and buffer. The PCR mixture contained $5 \times$ Phusion HF buffer $(5 \mu \mathrm{l}), 50 \mathrm{mM} \mathrm{MgCl}_{2}(1 \mu \mathrm{l})$, $10 \mathrm{mM}$ dNTP $(0.5 \mu \mathrm{l})$, forward and reverse primer $(1.25 \mu \mathrm{l}$ each), 100\% DMSO $(0.75 \mu \mathrm{l}), 2 \mathrm{U} / \mu \mathrm{l}$ Phusion DNA Taq polymerase $(0.25 \mu \mathrm{l})$, template cDNA (approx. $25 \mathrm{ng}$ ), and autoclaved Milli Q water to make the final volume $25 \mu \mathrm{l}$. 
The cycling conditions used were: initial denaturation at $98^{\circ} \mathrm{C}$ for $30 \mathrm{~s}$ followed by 35 amplification cycles consisting of denaturation at $98{ }^{\circ} \mathrm{C}$ for $15 \mathrm{~s}$, annealing at $57{ }^{\circ} \mathrm{C}$ for $30 \mathrm{~s}$ and extension at $72{ }^{\circ} \mathrm{C}$ for $30 \mathrm{~s}$, followed by a final extension at $72{ }^{\circ} \mathrm{C}$ for $5 \mathrm{~min}$. The PCR products were visualized in $1.2 \%$ agarose gel followed by sequencing.

\section{Results and discussion}

\section{RNA quality assessment and downstream processing}

Distinct and intact $28 \mathrm{~S}$ rRNA and $18 \mathrm{~S}$ rRNA bands without any DNA contamination and RNA shearing was observed in agarose gels (Fig. 1). The protocol was successful in extracting good-quality RNA from both tuberous and rhizomatous species of Dioscorea and from different tissue types (Fig. 1). Spectrophotometric study revealed that the A260/A280 ratio of most of the RNA samples was in the range of 1.9-2.0 indicating high purity of the samples. The yield of RNA was satisfactory and in the range of $400-800 \mu \mathrm{g} / \mathrm{g}$ plant tissue used. The RNA integrity number (RIN) for samples tried was above eight (in 1-10 scale) which indicated that the RNA isolated using this protocol is of high quality and integrity (Fig. 2) and can be efficiently used for different purposes including NGS procedures.

Partial and full-length coding sequences were amplified from the RNA extracted using our protocol (Fig. 3). The size of the full-length coding sequence of storage protein dioscorin (dio A1) obtained was 1040 bp. Amplification of full-length coding sequence established the integrity of the extracted RNA. Although the protocol was originally modified to be used for tuber tissues, it was also successfully used for shoot and leaf samples. For aerial tissues, a single chloroform-isoamyl alcohol step after phenolchloroform-isoamyl alcohol step was sufficient unlike the tuber samples which needed an additional chloroformisoamyl alcohol step.

\section{RNA extraction methodology}

The CTAB method of RNA was found to be most effective for RNA extraction in Dioscorea when compared to TRIzol, guanidinium thiocyanate (Chomczynski and Sacchi 1987), and commonly used RNA extraction kits (Sigma, Qiagen RNeasy Plant Mini Kit). Although the extraction kits performed well for leaf and shoot tissues, clogging of columns was very common in extraction of tuber tissue. Slightly modified CTAB methods have been found useful for RNA extraction from many plant taxa that are rich in secondary metabolite content, e.g., Pinus (Chang et al. 1993), Vitis (Gambino et al. 2008), Hippophae (Ghangal et al. 2009), and Hylocereus (Wong et al. 2014). The protocol reported by us was modified mainly from the CTAB protocols of Chang et al. (1993) and Ghangal et al. (2009) as described below.

The CTAB buffer used in the study was prepared according to Chang et al. (1993) except that we used PVPP instead of PVP and did not use L spermidine. After trying a range of centrifugation conditions $(10,000-15,000 \mathrm{~g})$, it was found that a speed of $15,000 \mathrm{~g}$ was most effective for extracting RNA from our samples. This is unlike the previous protocols (Chang et al. 1993; Ghangal et al. 2009) where a lower range of centrifugation speed $(10,000-12,000 \mathrm{~g})$ was used. Although phenol is efficient in removing proteins while extraction, there are various concerns about using phenol. It is believed that phenol causes brownish precipitation and degradation of poly $\mathrm{A}$ tails (Chang et al. 1993). We did not face any problems of either efficiency or integrity of the RNA using phenolbased extractions. Polyphenolic compounds (secondary metabolite) present in samples are oxidized to form
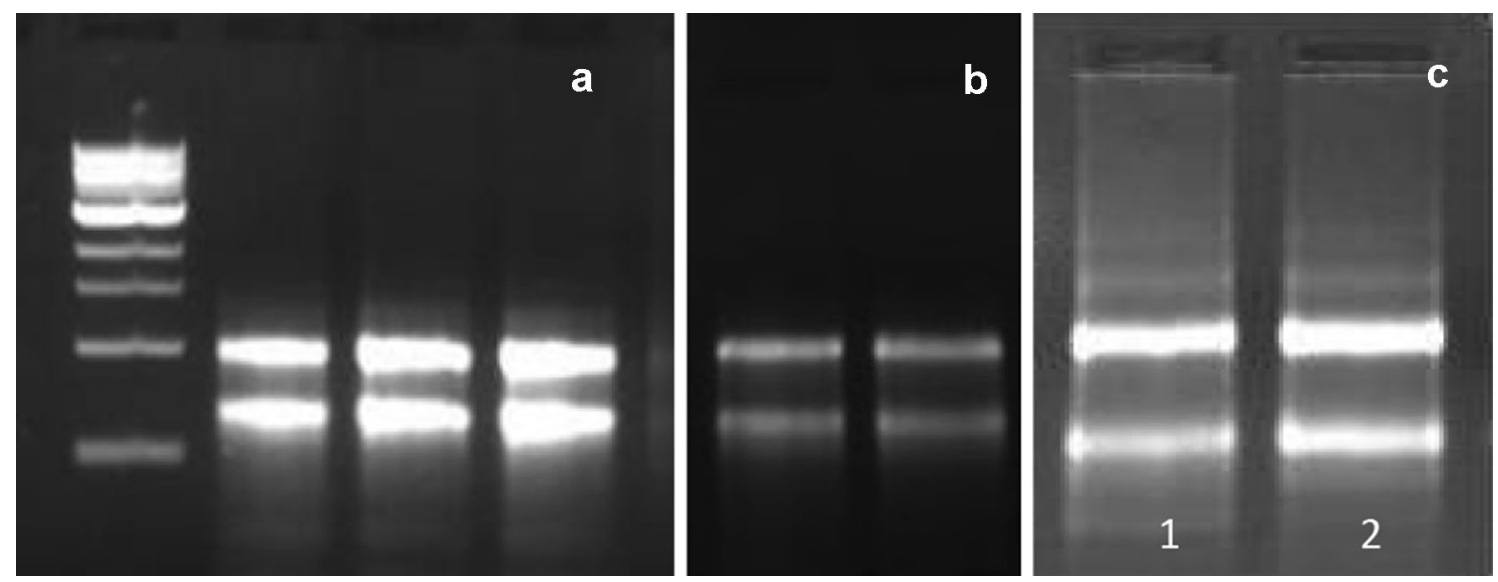

Fig. 1 High-quality RNA from Dioscorea samples generated using CTAB protocol. The RNA profile observed here is resolved in $1.5 \%$ agarose gel made in TBE buffer. Gel profiles shown are a D. alata tuber RNA, b D. deltoidea rhizome RNA, c D. alata shoot (1) and leaf (2) RNA 
Fig. 2 RNA integrity (RIN) profiles of Dioscorea alata tuber RNA sample generated by ABI Bioanalyser (in Centre for Cellular and Molecular Platforms, C-CAMP,

Bangalore). These high-quality RNA sample was successfully used for transcriptome sequencing using illumina $\mathrm{Hi}$ Seq 1000 platform

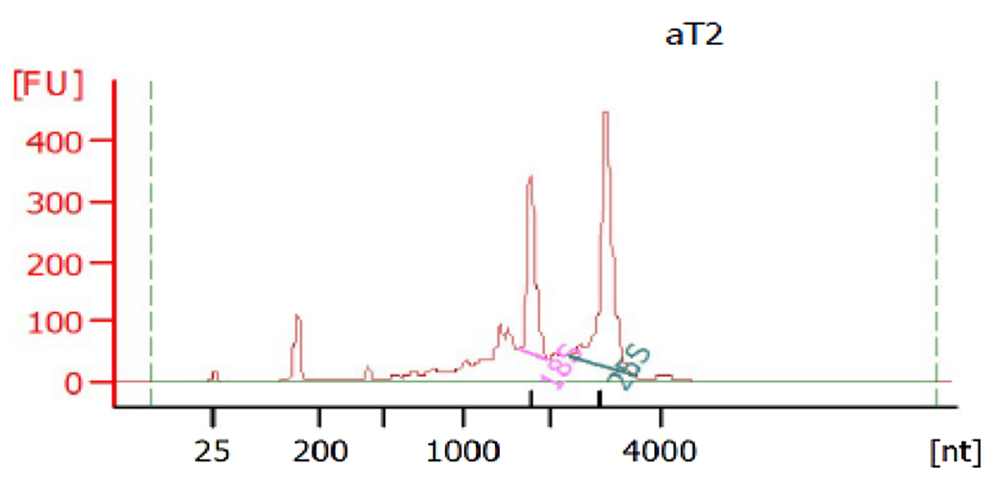

Overall Results for sample 4 :

RNA Area:

RNA Concentration:

rRNA Ratio [25s / 18s]:

RNA Integrity Number (RIN):

Result Flagging Color:

Result Flagging Label:

\section{aT2}

$2,756.9$

$977 \mathrm{ng} / \mu \mathrm{l}$

1.9

8.1 (B.02.08)

RIN: 8.10

\section{Name Start Size [nt] End Size [nt] Area \% of total Area}

$\begin{array}{lllll}18 S & 1,637 & 1,980 & 417.3 & 15.1 \\ 25 S & 2,387 & 3,555 & 801.7 & 29.1\end{array}$

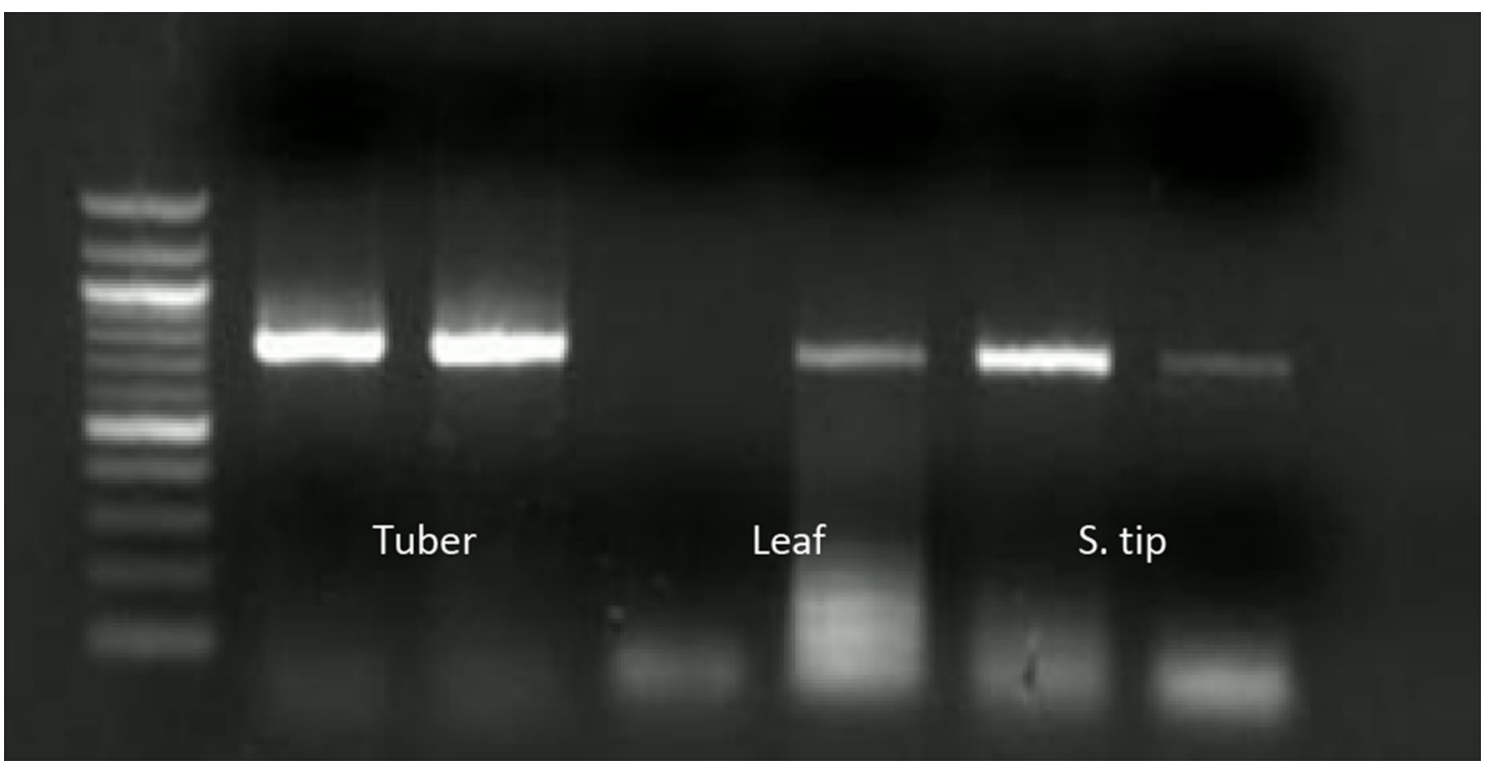

Fig. 3 Amplification of genes (dioscorin, partial) using RNA extracted from different tissues of Dioscorea using the CTAB protocol. The amplicons shown in the gel were from tuber, leaf, and shoot tip RNA of D. alata

quinones which bind with nucleic acid while extraction and cause trouble in downstream processes like RT-PCR (Salzman et al. 1999). Reducing agents like PVP/PVPP and beta-mercaptoethanol help to overcome this problem (Chang et al. 1993). PVP is not compatible with phenol (Ghangal et al. 2009; Salzman et al. 1999) and hence was replaced by PVPP in our protocol. In addition, beta- mercaptoethanol helps to denature RNases (Wong et al. 2014). The chloroform-isoamyl alcohol step after the phenol-chloroform-isoamyl alcohol step is crucial as it helps to remove residual phenols. (Ghangal et al. 2009). The previous protocol suggested use of one washing step with chloroform-isoamyl alcohol (Ghangal et al. 2009), but we got the best results by repeating the chloroform- 
isoamyl alcohol washing step until the supernatant was clear.

We found that precipitation using lithium chloride was more effective than ethanol-based precipitation method (Ghangal et al. 2009). A major advantage of lithium chloride is that it does not efficiently precipitate either protein or DNA and thus helps to reduce contamination by these compounds. The RNA obtained in our protocol was free from DNA as observed in gels, this might be because of the use of saturated phenol at low $\mathrm{pH}$ and lithium chloride, both of which promote RNA extraction. Optional DNase treatment can be done after extraction, as it did not degrade the quality of the RNA. Use of salts is a common practice in RNA extraction procedures to dissolve polysaccharides and to remove CTAB (Chang et al. 1993; Aljanabi et al. 1999). Washing the RNA pellet with $4 \mathrm{M}$ $\mathrm{NaCl}$ yielded RNA of better quality than RNA recovered without a $\mathrm{NaCl}$ washing step. The $\mathrm{NaCl}$ washing step was used in previous protocols (Ghangal et al. 2009); however, we used a lower concentration of $\mathrm{NaCl}$ (4 $\mathrm{M}$ rather than $5 \mathrm{M}$ ) and a single washing step (rather than two). This did not affect the quality of RNA obtained and saved time in extraction. The extraction protocol is short except for the overnight precipitation step using lithium chloride. We found that extraction time could be reduced by limiting the precipitation step to 1-4 h; however, overnight precipitation is much better as it results in better yield of RNA.

\section{Conclusion}

We extracted RNA of high RIN value (and used for transcriptome sequencing) following a modified CTAB protocol. Amplification of full-length coding sequence using oligo-dT as the reverse primer also establishes the integrity of the extracted RNA. Downstream use like transcriptome sequencing requires RNA at high concentration. Our protocol fulfills this requirement. The protocol developed successfully dealt with the high levels of mucilage and secondary metabolite content of tubers of Dioscorea. These components vary at different developmental stages of Dioscorea and our protocol was useful at all stages. Although we developed the protocol to extract RNA from tubers, extraction was also successfully used on rhizomes, roots, shoots and leaves. Thus this protocol can be universally applied in Dioscorea, and might be useful for other tuberous plant species or those with high mucilage and secondary metabolite content.

Acknowledgments The work was supported by a DU R\&D Grant and DU DST Purse Grant sanctioned to R. Geeta. The authors are grateful to University of Delhi for facilities, the Director CTCRI for the tuber samples, the Director of C-CAMP Bangalore for RIN determination and Prof. Renu Deswal and her students for their support.

\section{Compliance with ethical standards}

Conflict of interest The authors declare that they have no conflicts of interest in the publication.

\section{References}

Aljanabi SM, Forget L, Dookun A (1999) An improved rapid protocol for the isolation of polysaccharide and polyphenol-free sugarcane DNA. Plant Mol Biol Rep 17:1-8

Chang S, Puryear J, Cairney J (1993) A simple and efficient method for isolating RNA from pine trees. Plant Mol Biol Rep 11:113-116

Chomczynski P, Sacchi N (1987) Single-step method of RNA isolation by acid guanidinium thiocyanate-Phenol-chloroform extraction. Anal Biochem 162:156-159

Gambino G, Perrone I, Gribaudo I (2008) A rapid and effective method for RNA extraction from different tissues of grapevine and other woody plants. Phytochem Anal 19:520-525. doi:10. 1002/pca.1078

Ghangal R, Raghuvanshi S, Sharma PC (2009) Isolation of good quality RNA from a medicinal plant Seabuckthorn, rich in secondary metabolites. Plant Physiol Bioch. 47:1113-1115. doi:10.1016/j.plaphy.2009.09.004

Mignouna H, Abang MM, Asiedu R, Geeta R (2009) Dioscorea, true yams - a biological and evolutionary link between eudicots and grasses. In: Emerging model organisms. Cold Spring Harbor Laboratory Press, New York, p 73-79

Salzman RA, Fujita T, Salzman KZ, Hasegawa PM, Bressan RA (1999) An improved RNA isolation method for plant tissues containing high levels of phenolic compounds or carbohydrates. Plant Mol Biol Rep 17:11-17

Schroeder A, Mueller O, Stocker S, Salowsky R, Leiber M, Gassmann M, Lightfoot S, Menzel W, Granzow M, Ragg T (2006) The RIN: an RNA integrity number for assigning integrity values to RNA measurements. BMC Mol Biol 7:1-14. doi:10.1186/14712199-7-3

Wong LM, Silvaraj S, Phoon LQ (2014) An optimized high-salt CTAB protocol for both DNA and RNA isolation from succulent stems of Hylocereus sp. JOMB 3:236-240. doi:10.12720/jomb.3. 4.236- 240 